also given. The guide is an interesting and comprehensive account of the area.

The coastal conferences were designed with a more definite aim in view. Studies of constal areas by the local planning authorities were first called for in 1963 by the Ministry of Housing and Local Government Development plans were to be considered in relation to conservation of natural attractions, places and nature of amenities for holidaymakers and arcas of special scientific interest. The ministry asked the National Parks Commission to arrange conferences to coordinate the plans of the various local authorities. In the meantime, additional studies are in motion, investigating aspects of the problem of coastal development in terms of social, economic and recreational factors. Places of scientific interest are being identified and classified by the Nature Conservancy. The conference on Hampshire and the Isle of Wight, which was held in Southampton in June 1966, began with a reminder that industrial requirements must be considered alongside any developments for holidaymakers. The conference procecdings form the first part of the report, the rest being given to written reports from planning officers in the area, statistics of land use of the 133 miles of coastline, and the movement of retired people to the area, with accompanying social problems. A map summarizes the development and protected areas along this section of the coast, with figures for visitors in main resorts. Coastal eyesores such as wartime remains, rubbish tips and abandoned vessels have also been listed. These are encouraging steps in coastal planning and improvement. While waiting for the results of all the conferences, the ministry has called for a "holding operation" so that the coasts are protected until a definite policy has been worked out.

\section{Research in Education}

The twenty-first annual report of the National Foundation for Educational Research in England and Wales has recently been published. During the year the foundation transformed itself into an incorporated organization (a company limited by guarantee). The purpose of this change was to give the foundation a separate legal existence. Sir Francis Hill, chairman of the Executive Committee, retired and was replaced by Sir Alan Lubbock.

According to the report, these changes in the foundation's financial and administrative structures have been matched by a continuing process of change in the whole field of research in education. Between 1966 and 1967, two bodies-the National Advisory Council for Educational Technology and the Committee on Research and Development in Modern Languageswere set up in addition to the Schools Council. Each of these has considerable government finance bchind it and is likely to undertake or commission research work which will involve the schools. It has also been suggested that something similar should be set up for teacher education and training. Another new development is the setting up of a Planning Branch by the Department of Education and Science to undertake research in education through its own staff and through staff specifically employed for particular projects. This new department, it is stated, will concentrate on relatively short-term studics mainly in the field of economic research.
Three new developments which reached an advanced stage during the year were: the first issue of the foundation's newrsletter, Educational Research News; the development of research paperbacks which are now in the press; and the production of pamphlets, setting out the practical applications in schools of the foundation's recent rosearches, which will be ready in the new year.

The foundation has supported mathematics research, reading research and research on the tcacher's work and training. In addition, research projects in technical and further education have been continued. A Constructive Education Project, sponsored by the Home Office and the Department of Education and Science, is investigating the influence of schools on children with particular reference to their achievements, attitudes and behaviour. The project, which was starterl in 1964, will continue for eight years.

Over the two years from 1965 to 1967 , sponsors have increased finance for projects by 125 per cent and this now accounts for a considerable portion of the foundation's finances. Generally, finances for the work of the foundation are drawn from two main sources, subscription income and contract finance, both of which are controlled by the board.

During the year the basic subscription income increased slightly to $f 64,133$ and income from publications rose significantly to $£ 8,600$. Work on sponsored projects increased by approximately 23 per cent over the previous year while grant-in-aid from the Department of Education and Science remained at $£ 20,000$.

\section{Currents in the Atlantic}

THE research vessel Discovery was brought back to her home port, Plymouth, on Monday this week after a two month cruise in the east Atlantic under the leadership of Dr J. C. Swallow of the National Institute of Oceanography. Most of this cruise was concerned with taking an initial look at deep current patterns over a reasonably extended period, now that the techniques for doing this are becoming available. The basic current meter used on this cruise is a device made in the United States, but the ancillary equipment which has enabled the maximum information to be derived from it has been specially developed at the National Institute of Oceanography. Anchored deep current buoys were put down on the flat "bottom plain" at the mouth of the Bay of Biscay. These were positioned about 30 miles from each other and made measurements at three levels $-400 \mathrm{~m}, 1,200 \mathrm{~m}$ and at bottom water below $2,500 \mathrm{~m}$. The deepest position was at $4,800 \mathrm{~m}$ wherc a buoy remained for 5 weeks. The others were in position for shorter periods but still of the order of weeks.

Because so little is known of the long term fluctua. tions of deep currents, three drifting floats given neutral buoyancy to remain at similar depths were used as a check for the buoy measurements. The floats contained an acoustic beacon with a range of 4-5 miles to show the way the instruments drifted in the current. Dr Swallow said he was surprised that there were not more fluctuations in the currents measured. Findings from the floats alone indicate that the deeper level currents tend to move faster, but from this cruise it was found that there was always a rclationship of gencral direction between the three currents when 